Article

\title{
Form and Function in Two Traditional Markets of the Middle East: Souq Mutrah and Souq Waqif
}

\author{
Mark David Major *(1) and Heba O. Tannous (1) \\ Department of Architecture and Urban Planning, College of Engineering, Qatar University, Doha 2713, Qatar; \\ heba.tannous@qu.edu.qa \\ * Correspondence: m.major@qu.edu.qa; Tel.: +974-3136-0842
}

Received: 7 July 2020; Accepted: 24 July 2020; Published: 2 September 2020

\begin{abstract}
This paper presents some of the findings of a study comparing the form and function of two traditional markets on the Arabian Peninsula: Souq Mutrah in Muscat, Oman, and Souq Waqif in Doha, Qatar. Globalization and rapid urbanization characterize both Doha and Muscat, which share similar historical origins as coastal settlements despite stark differences in topography; Oman is mountainous, whereas Qatar is flat. We investigate the urban morphology, land use and function of the two souqs using several representational techniques typical of morphological research, including space syntax analysis. The purpose is to develop a deeper understanding of (1) the evolution of space and form in these marketplaces over time, and (2) the possible implications for their functioning as urban places. The analysis demonstrates the critical importance of the contextual relations at the macro- and micro-scale of the urban environment for understanding the complex nature of these souqs as places today, helping to deepen our knowledge about traditional markets in the Middle East.
\end{abstract}

Keywords: land use; markets; morphology; topography; urban studies

\section{Introduction}

The economic viability and social sustainability of traditional marketplaces or 'souqs' is a hot-button issue in cities undergoing globalization and rapid urbanization in the Arabian/Persian Gulf and broader Middle East and North Africa (MENA) region. MENA is an acronym lacking standard definition. Generally, it refers to the vast region stretching east-to-west from Iran to morocco and roughly synonymous with the Arab World. The following is a list of commonly-included countries: Algeria, Bahrain, Egypt, Iran, Iraq, Palestine, Jordan, Kuwait, Lebanon, Libya, morocco, Oman, Qatar, Saudi Arabia, Syria, Tunisia, the United Arab Emirates (UAE) and Yemen. Different organizations sometimes include Turkey, Cyprus, Northern Cyprus, Sudan, Mauritania, Somalia and Chad as part of MENA as well.

The loss of traditional urban fabric to contemporary development in many of the cities in these countries ties together issues of urban morphogenesis and the socio-economic sustainability of souqs. Space syntax theory and methods seem well-suited to objectively investigate the connection between urban morphology, evolution and the performance of these traditional marketplaces in the past, present and future. We utilize space syntax modeling techniques in this paper to contextualize two traditional souqs within their metropolitan region to describe the spatial processes at work in the urban street network. Such an approach can help us to tailor potential interventions based on the objective parameters of network science, making a sensitive link between the morphological evolution of traditional marketplaces in cities and their long-term economic sustainability as urban places.

In human history, marketplaces have played a critical role in the economic, political and social evolution of many settlements, from the agora and forum of the Ancient Greco-Roman World to Middle Eastern souqs and medieval European bastide towns to contemporary strip and 
shopping malls. marketplaces often serve as a focal point in the physical and spatial structure of settlements around the world, including the Arabian Peninsula. The Arabian Peninsula consists of six countries forming the Gulf Cooperation Council (GCC)—Bahrain, Kuwait, Oman, Qatar, Saudi Arabia and the United Arab Emirates (UAE) - encompassing about 3.2 million square kilometers $\left(\mathrm{km}^{2}\right)$ (Figure 1). The Levant and Arabian/Persian Gulf define the peninsula to the north and northeast, respectively. The Levant refers to a large area in the Eastern mediterranean, primarily in Western Asia associated with the Ancient Near East, consisting of Cyprus, Jordan, Lebanon, Palestine and Syria today. The Indian Ocean borders the peninsula to the south and the Red Sea to the west. Diverse geography characterizes the Arabian Peninsula, ranging from a vast central plateau to the stony desert in the north, dunes to the east and coastlands that are resplendent with coral reefs in the Red Sea and mountains in Oman and Yemen to the southeast.

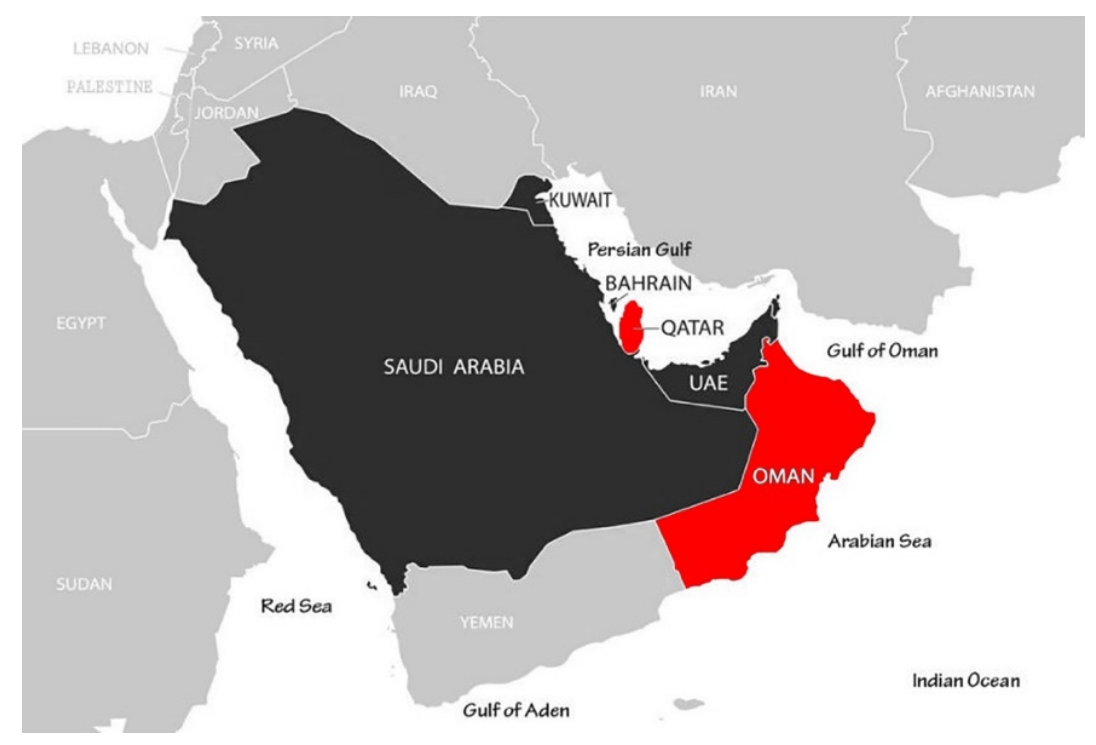

Figure 1. Map showing the Gulf Cooperation Council (GCC) countries in black, with Qatar and Oman highlighted in red.

Traditional marketplaces (souq "سوق") in Arabic-speaking countries date back to at least the 6th Century BCE [1]. Generally, souqs are publicly-accessible pedestrian markets with arcades, plazas and numerous shops where people regularly gather to purchase and sell goods, socialize and walk. Some are street-oriented retail areas. Others are covered, outdoor or indoor. Some are permanent, whereas others are temporary. There is no universally agreed definition.

Initially located outside city walls, souqs shifted to city centers as urban populations grew. In Islamic countries, the Friday mosque usually forms the heart of the settlement, with an adjacent souq serving as an important facility to support people's daily activities. Friday prayer has great significance. The Qur'an invokes the importance of Friday as a sacred day for worship when people gather and pray together in the main mosque. The term souq possesses many alternatives in different parts of the world, including socco (a corrupted Spanish term) in northern morocco and bazaar in Iran. Words in the Arabic language tend to be more expansive in meaning, but we attempt to explain these terms in English. The paper tends to use the Arabic word, souq. The word bazaar also tends to identify areas of a souq selling specialized goods, such as the 'spice bazaar' and 'textile bazaar' in the Old City of Jerusalem. However, locals often use the word souq similarly, so there is a souq within a souq, i.e., the Gold Souq.

The traditional market of Souq Waqif emerged near a dry river bed known as Wadi musheireb early in the founding of Doha, Qatar, in the 1820s [2]. There is evidence of communal activity in the area around Muscat, Oman dating to the 6th millennium BCE, and Greek geographer Ptolemy refers to the suitability of Muscat as a port as early as the 1st Century CE, calling it Cryptus Portus ('the Hidden 
Port') [3]. Souq Mutrah in Old Muscat dates to the early-to-mid 19th century, when Said bin Sultan re-established the naval supremacy of Muscat over the Arabian Gulf in an alliance with the United States [4]. Said bin Sultan was the last ruler of the Omani Empire from 1806-1856. Both souqs possess a maze-like series of (mostly pedestrian) pathways leading in and out of the area. They sell a variety of goods and services and attract many different types of users today (Figure 2).
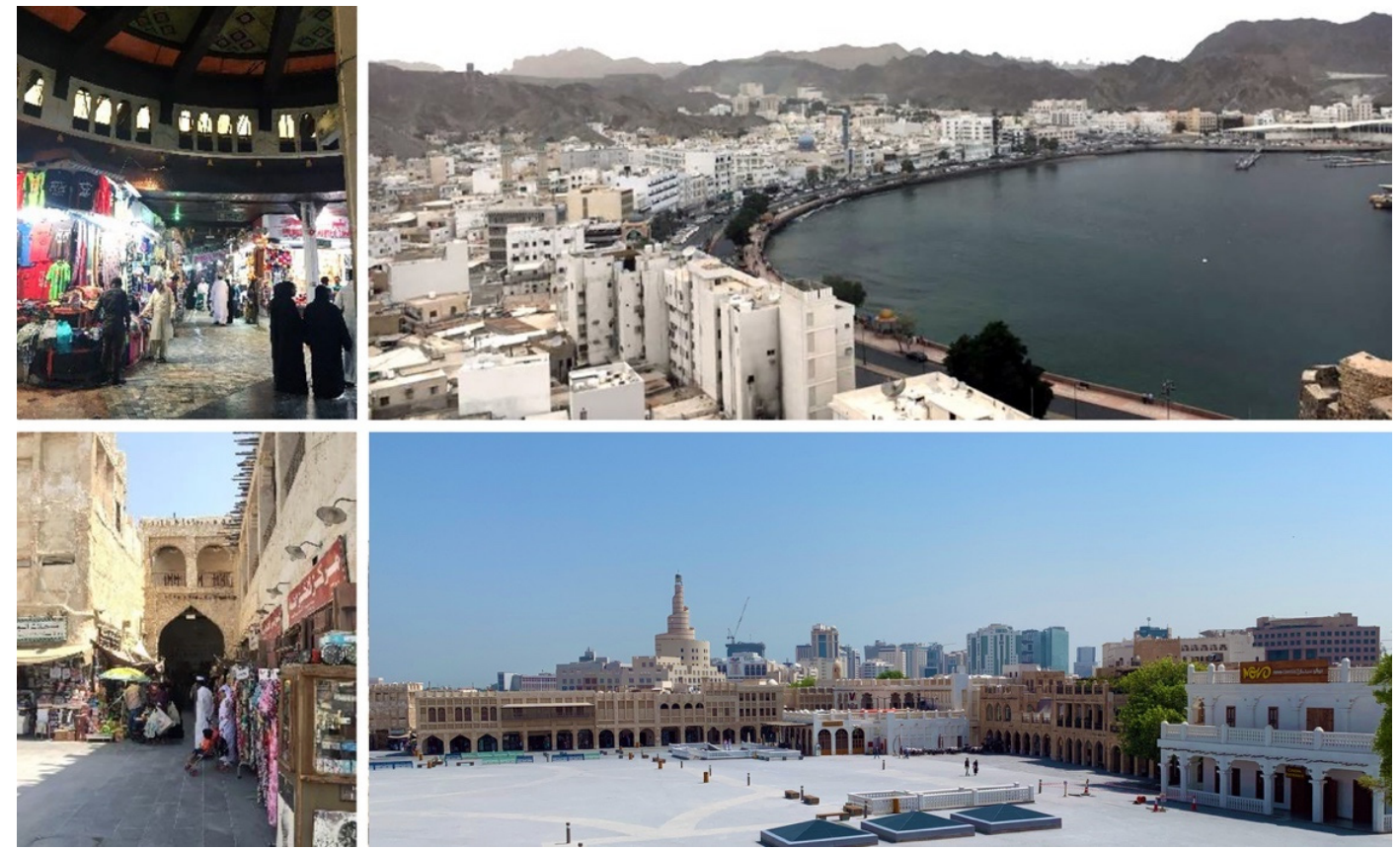

Figure 2. Interior and aerial views of the (top) Souq Mutrah in Muscat and (bottom) Souq Waqif in Doha [5].

Many people left the old city centers during the initial stages of globalization, rapid urbanization and economic development of the cities in the Arabian Peninsula. It led to deterioration and neglect in many traditional marketplaces despite renewed interest in the inherent value of public spaces in general and heritage preservation of traditional areas in Arab cities in particular [5-7]. Historically, the local economics of supply and demand for selling produce goods drove these traditional markets. The effects of globalization, international supply chains, market demand and the evolution of socio-cultural characteristics in Middle Eastern cities contributed to a transformation of traditional souqs. many continue to thrive by embracing change, and new uses such as restaurants, cafés and souvenir shops catering to international tourism. Others appear diminished. The spaces within souqs often facilitate a need for economic exchanges, social interactions and unplanned encounters in communal life among a diverse range of users. Such places can generate civic value in support of community cohesion and enhance the quality of urban space in promoting sustainable cities [6].

The complex role that souqs appear to play as physical and cultural mechanisms in everyday life of the urban environment is a worthy subject of investigation. This paper conducts morphological analysis to understand better how Souq Mutrah in Muscat and Souq Waqif in Doha responded as spatial objects to the realization and transformation of a multitude of factors during rapid urban expansion over time. At its heart, the fundamental question of this research is: what are the morphological characteristics of the two souqs, with a subset question being: how might they be alike or different from each other? The scope of this research is multidisciplinary, involving aspects of urban studies, architecture, history and other integrated social sciences, but is also specific to issues of the built environment, markets and urbanism in the MENA region. The goal is to understand both souqs as urban places beyond mere differences of style, how these markets fit and operate within their urban 
context, and attempt to objectively describe these markets as urban places in the history, function and evolution of Muscat and Doha, respectively.

To answer these questions, we summarize the methodology of the study and its limitations. We then briefly review the literature about souqs in general, urbanism in the Gulf Region-specifically with regards to Muscat and Doha-and the historical background and evolution of Souq Mutrah and Souq Waqif as urban places. We summarize some of the findings of the research into these two souqs. Finally, the paper concludes by discussing the implications for future research and design interventions in the traditional urban fabric of Middle Eastern cities.

\section{Research Methodology and Limitations}

The research focus of this study is the urban morphology of the two souqs within their immediate and metropolitan urban context. Urban morphology is the study of form in cities, and the components of the urban tissue, such as streets, squares and other public spaces, that give shape to the spatial network. morphological research tends to focus on the formation and transformation of physical cities over time, the spatial pattern of street networks at different scales, and other physical characteristics that might inform appropriate design interventions in the promotion of sustainable urban development [8]. Such studies seek to understand the shape, form, arrangement, spatial structure and character of settlements by identifying the pattern of their components and the process of their development. This study analyzes the urban morphology of Doha and Muscat by utilizing several cartographic sources indicating building footprints and street layout, including historical maps where available.

The methodology of the study aims to identify the key concepts and themes useful for understanding these souqs, the nature of the users, and how the souqs currently operate within their immediate context and metropolitan region. We take a generalist, interdisciplinary approach to the literature to summarize the historical evolution of souqs, and their nature as physical entities and social experiences of significance in the life of the city. The study includes qualitative descriptions of historic (where available) and contemporary materials such as maps and photographs to help pull together the story of Souq Mutrah and Souq Waqif. Time and resources limited the scope of the research. Other restrictions included a lack of documented resources and map inaccuracies. Researchers made site visits to Souq Mutrah in march 2019 and Souq Waqif in march, June and September 2019 for data collection, observations and mapping verification to compensate for these limitations. We had to utilize multiple methods of qualitative observation within a short time to compare the two souqs under similar circumstances.

The researchers conducted extensive space syntax modeling of the souqs within their metropolitan surroundings at various scales, but only briefly summarize the most relevant findings of this analysis with reference to a previous paper [9]. The purpose is to describe the spatial processes at work in both cities using space syntax theory and demonstrate the fundamental relationship to their morphological evolution and long-term sustainability as urban places. Space syntax proves useful for a more in-depth understanding of the morphological differences between the souqs and their cities in helping to address a gap in our knowledge about Arabian cities. The study makes extensive use of figure-ground representations to compare, contrast and analyze the urban form, space, pattern, scale and edge definitions of the souqs using the poche technique where space is black and blocks/buildings are white. We created these figure-ground representations based on available maps and satellite imagery [10-16].

\section{General Background about Souqs and Gulf Urbanism}

According to scholars, a multifunctional core of religious, educational and civic facilities, souqs, and single-story courtyard houses tends to characterize the oldest Islamic settlements. Components of this multifunctional core interconnected via narrow streets and passageways. The grand mosque complex formed the center. markets surrounded the complex, often immediately adjacent to its entry gates. Entry to the mosque required passing through the souq [17]. In The Image of the City, 
Lynch describes Islamic settlements as 'inward cities' because they often seem closed and private [18]. The street layout of such settlements seems to consist of a few main streets, many smaller local routes leading to narrow, blind alleys providing access to the intensely-private entrances of individual dwelling units. Researchers often use the typological descriptions of public, semi-public, semi-private and private, derived from Alexander et al., to characterize the labyrinthine-like street pattern of Islamic settlements [19] (Figure 3).
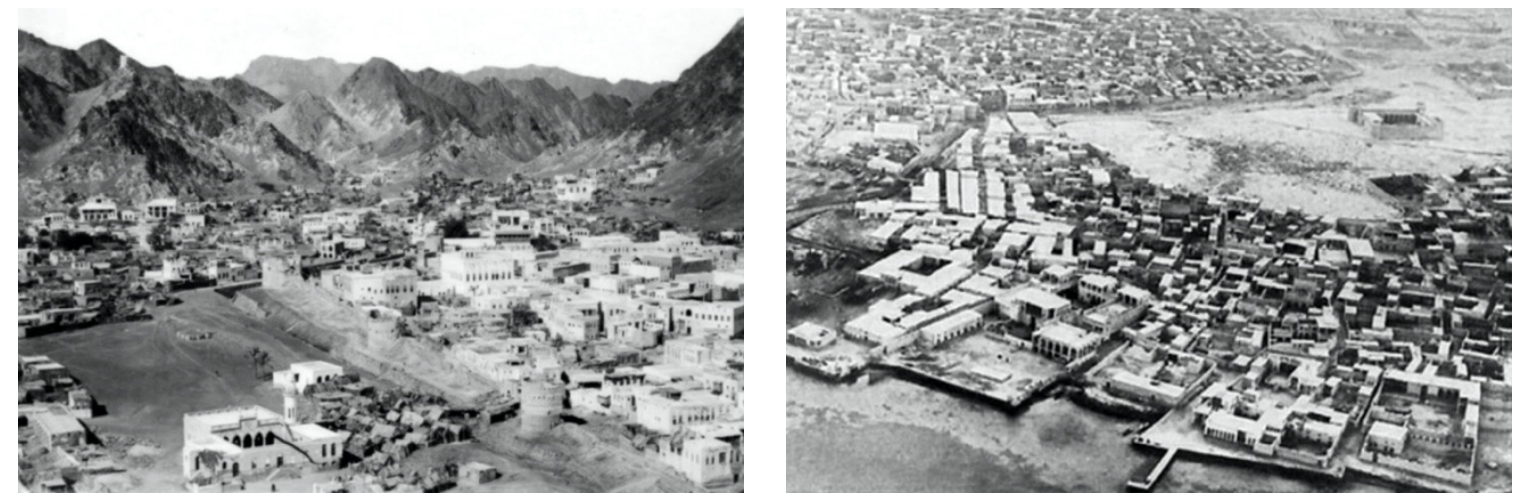

Figure 3. Aerial historical photographs of (left) Old Muscat showing the Mutrah area circa 1900, and (right) Old Doha showing Souq Waqif in the 1940s. The oldest segment of the historic spine in Souq Waqif is discernible due to the larger urban blocks on the left side of the image $[20,21]$.

However, Major et al. argue using space syntax that the spatial and social logic of such street networks is very sophisticated, which they describe as hierarchal separation by linear integration [22]. They argue that such spatial structures emerge naturally-based on Hillier's laws of spatial emergence-from the restricted random aggregation of dwelling units following simple rules, which were first described by Hillier and Hanson about European settlements [23,24]. Major et al. suggest that this represents a near-universal plan model in many older settlements of the world, especially in the Ancient Near East, more or less coinciding with the modern MENA region [22]. It clearly distinguishes between the center, edge and interstitial streets in settlement form without requiring top-down planning regulation or maximizing disconnections, as in American suburban models. Islamic societies merely adopt two additional local rules during this restricted random aggregation process, governing the location of dwelling entrances and windows overlooking yards, which gives rise to their distinctive pattern as urban places over time [22,25].

As traditional marketplaces in the Gulf Region, Souq Mutrah and Souq Waqif share several similarities. In the same way, Muscat and Doha share similarities as coastal settlements based initially around the pearling (the practice of diving for pearls) and fishing industries, and later globalization and rapid urbanization. Both countries also have short cool, dry winters and long hot, humid summers, with average temperatures varying from $12{ }^{\circ} \mathrm{C}$ in January to $50{ }^{\circ} \mathrm{C}$ in July. However, the evolutionary transformation of Doha and Muscat as urban objects differed in significant ways over time. Nonetheless, both souqs played a fundamental role in the historical development and contemporary nature of both cities as distinctive socio-economic and cultural entities [25].

Like Dubai in the UAE and Riyadh in Saudi Arabia (both growing 15-20 times over in population from 1965-1995), Muscat and Doha experienced significant population growth, demographic changes, infrastructure development and widespread urban expansion over the last half-century [25]. The newly-formed nation-state, land speculation, and political and economic competition for regional leadership were influential variables in shaping globalization and rapid urbanization in the region $[7,26]$. Large-scale urbanization is a relatively recent phenomenon on the Arabian Peninsula compared to the rest of the MENA region and the world in general. However, there is a long record of settlements on the Arabian Peninsula, perhaps dating at least 5000 years ago, especially along the coast of the Arabian/Persian Gulf, but at a smaller scale than in the Ancient Near East [9]. In the 1950s, 
the northeastern coast of the Arabian Peninsula remained mostly barren wilderness. However, an entirely different landscape emerged over the last fifty years, mainly focused around capital cities. Cities in the region experienced three distinctive phases of urban growth during the modern Era, beginning with the pre-oil period, then the discovery of oil and rapid growth, and the current post-oil transition to economic diversity underway in many Arabian cities [7,25] (Figure 4).

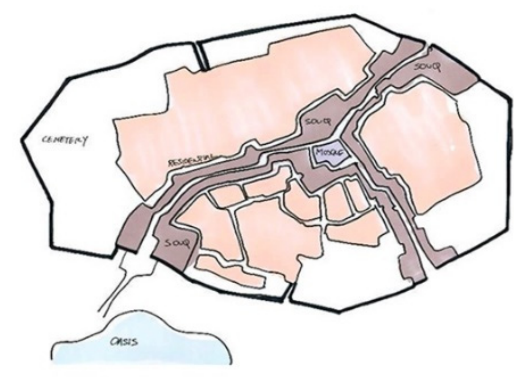

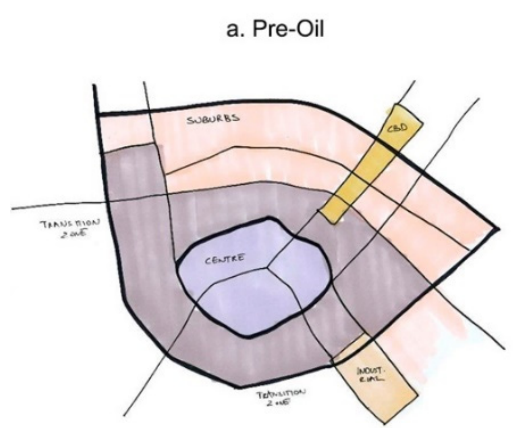

b. Oil

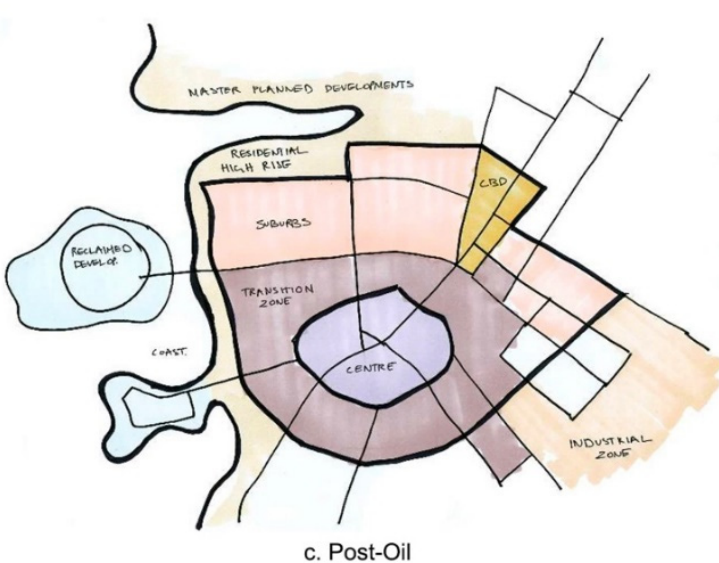

c. Post-Oil

Figure 4. Representative sketches of the urban form in the (a) pre-oil settlement (three times the scale relative to the other sketches), (b) oil city, and (c) post-oil metropolis of the Arabian Peninsula. Source: Drawing by Heba O. Tannous after Salama and Wiedmann $[7,22]$.

Environmental circumstances, local construction materials such as mud, rock, coral and palm fronds, and the scarcity of water tend to define the pre-oil settlements. Some located near to an oasis. For others, wadis or valleys provided seasonal water-originating in highlands due to annual flooding for settlements such as Muscat—or else they evolved near to transitory wells into the aquifer providing freshwater access, as in Doha. The Friday mosque usually served as a focal point of the settlements for communal events. There would be an adjacent souq, often extending linearly, and nearby private, residential areas with one-story dwellings.

The oil city led to economic prosperity. There was a dramatic growth in the scale of settlements due to peripheral housing developments, which led to an outflux of residents abandoning the old city centers. New high-rise business districts emerged, and large-scale industrial areas to the south due to predominant wind direction $[7,25]$.

Rising concerns about continuing dependency on oil revenues, and their potential decline arising from increased competition from Russia and the United States, drove investment plans for economic diversification in the post-oil cities of the Arabian Peninsula [7,27]. Large-scale infrastructure projects ('mega-projects') characterize much of this transformation, including land reclamation projects in the Arabian/Persian Gulf, new suburban districts, and satellite cities within enlarged metropolitan regions. The MENA region now teems with large-scale urban areas, operating almost like city-states within their respective countries. They have become desirable locations for companies, academic institutions and tourists from around the world. The initial production and exportation of oil and natural gas, and the subsequent transition to more diversified economies, fed an explosion of population growth, prosperity, mega-projects, and housing development [28,29]. 
In 2019, the population of the MENA region was approximately 457 million people across about 8.9 million $\mathrm{km}^{2}$. It represents about $6 \%$ of the total population and land area in the world [30]. It possesses a significant amount of petroleum $(\sim 57 \%)$ and natural gas $(\sim 41 \%)$ reserves in the world, mostly concentrated in the Gulf States of the Arabian Peninsula [31]. These reserves make the MENA region a vital source of global stability. It also represents the source of rapid urbanization and globalization trends in the region over the last fifty years. How traditional marketplaces such as souqs might respond to such drastic changes to evolve and thrive in the new urbanscape has become critically important to both the governments and citizens of these rapidly modernizing Arabian societies. As we shall see, Souq Mutrah and Souq Waqif appear to provide different-but entirely appropriate-answers to this problem, which adapt to the challenges of the topography for urban growth in Muscat and Doha, respectively (Figure 5).
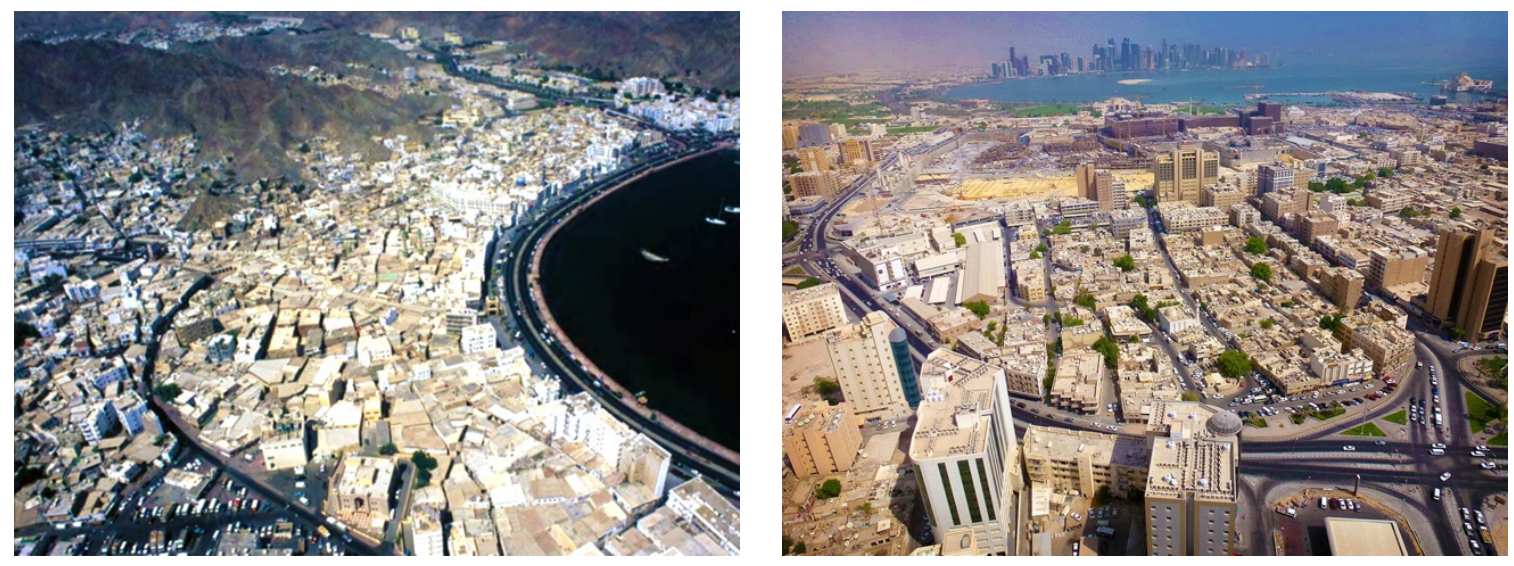

Figure 5. Bird's eye views of the urban fabric in (left) Old Muscat in Mutrah in 2005, and (right) Old Doha with Doha Bay and the modern skyscrapers of West Bay in the background in 2010 [32,33].

\section{About Souq Mutrah and Muscat}

Muscat Governorate is the capital city of the Sultanate of Oman. The governorate covers an area of $3900 \mathrm{~km}^{2}$ and consists of six wilayat (Arabic for provinces or states; the singular is wilayah), which are As Seeb, Bosher, Al-Amerat, Mutrah, Muscat and Qurayat. Muscat developed extensively within this capital region. Due to the mountainous, often inaccessible terrain surrounding the old city and port in the Mutrah wilayah (basically, Old Muscat), many individual settlements developed separately before their eventual incorporation into the expanded city of Muscat [7,25].

As Tannous and Major argue, these topographical conditions had a profound effect on the emergent spatial structure of metropolitan Muscat today [9]. These conditions gave rise to a predominantly linear city growing east to west along the coastline, principally governed by Sultan Qaboos Street and the Muscat Expressway. At the macro-scale of the urban spatial network, the metric distance from Old Muscat to the metropolitan edge at its furthest extent in the west is approximately $45 \mathrm{~km}$. To compensate for this linearity at the macro-scale, the local areas of Muscat prioritize compactness in street density (65 streets $/ \mathrm{km}^{2}$ in built areas only, excluding mountains and airport lands) and, by implication, population density at the micro-scale $[9,25]$. It is about the same street density as manchester in the United Kingdom, and 86\% of that in Barcelona, Spain [34]. The resolution of macro- and micro-scale demands on the urban spatial network weaves a polycentric spatial structure into the metropolitan region centered around the Old Muscat (e.g., Mutrah), Modern Muscat, Al-Amarat and Mawaleh areas [9] (Figure 6). The polycentric structure becomes apparent in the pattern of integration based on the mean depth from the most integrated street (12.8) — a long, central segment of the Major east-west Sultan Qaboos Street-in Muscat, excluding all one-connected lines. Excluding one-connected lines provides a purer picture of the distributive network in the space syntax model of a city using Major's methodology [34,35]. 


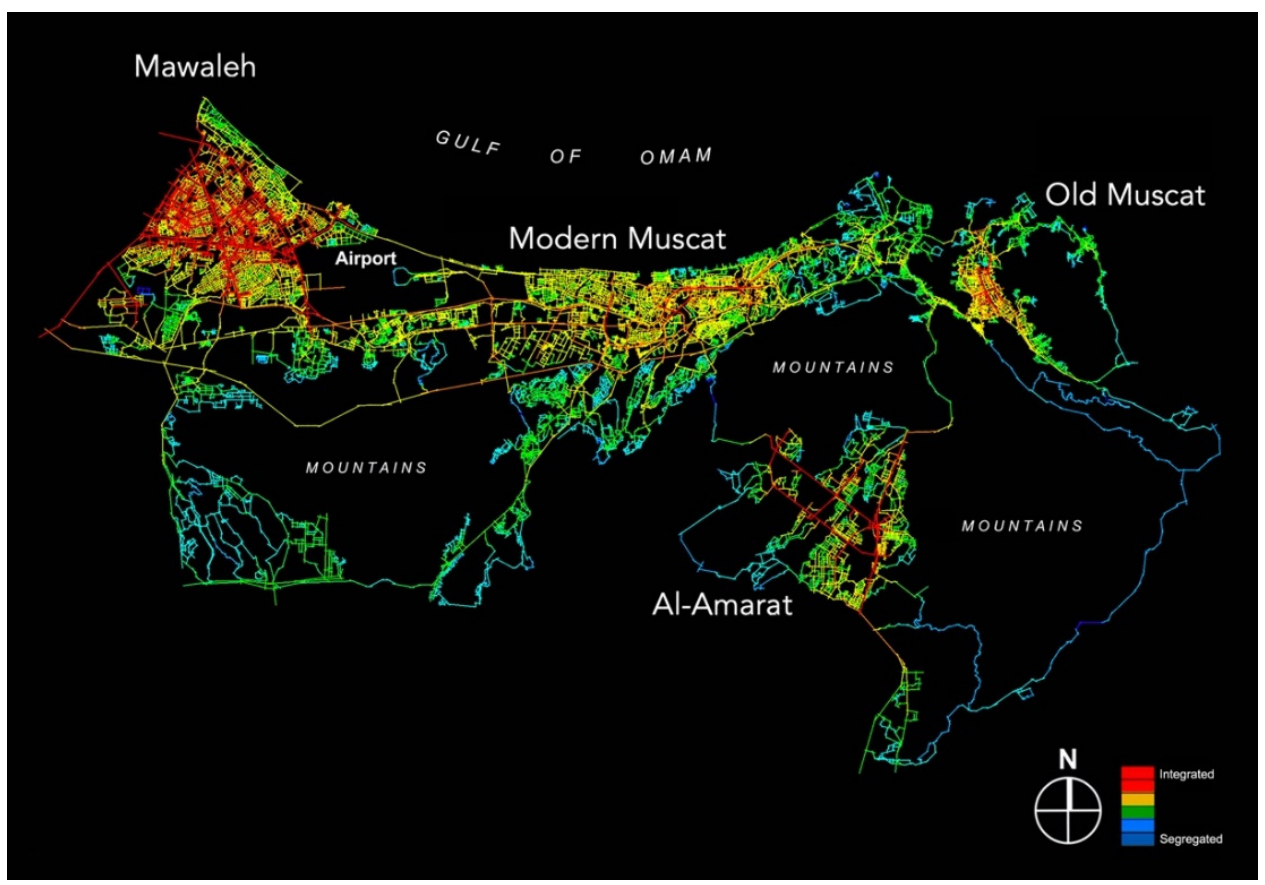

Figure 6. Pattern of integration (radius $=13$ ) in the space syntax model of metropolitan Muscat, Oman-based on mean depth from the most integrated street (12.8), i.e., a long, central segment of Sultan Qaboos Street in Modern Muscat-encompassing 14,662 streets without one-connected lines, over an approximate area of $720 \mathrm{~km}^{2}$ in 2018.

The Mutrah wilayah possesses sixteen wadis (i.e., valleys/creeks) and two main falaj (i.e., ancient water channels providing irrigation for agriculture and domestic use). Mutrah is also known for several sur ('walled communities') like Sur Jibroo, Sur Ruwi, the Sur of Old Mutrah, and Sur Al-Lawatiyah [11,25]. A sur ('سور' in Arabic) means a wall that could be a fence, rampart, enclosure, or fortification. It is a term referring to the walls of an enclosed community, similar to a bastide ('fortified town') in the medieval European tradition or a presidio in the Spanish tradition during the colonization of the New World [36].

Souq Mutrah is the oldest traditional marketplace in Muscat. It is adjacent to, running along, and extending inward from the Mutrah Corniche on the Gulf of Oman. Corniche is originally a French term, but it is common in the Gulf Region today. It means 'a road cut into the edge of a cliff, especially one running along a coast,' often involving reclaimed land such as in Muscat and Doha. [36]. The central spine extends from the main gate on the Mutrah Corniche promenade along the coast in the north and splits into two directions towards gateways in the south (Figure 7). Except for these gateways marking the entry points, Souq Mutrah does not possess well-defined, two-dimensional boundaries in plan. Individual retail units tend to bleed into and blend with the surrounding residential dwellings. For this study, the researchers defined a boundary based on where residential dwellings tend become more prevalent than retail units. The most explicit boundaries of Souq Mutrah are Mutrah Corniche/Al-Bahri Road to the north, Sur Lawatiyah to the northwest, and Mutrah High Street to the south and southeast. The main branch of the souq spine, Souq Al-Dhalam meaning 'darkness market' in Arabic, is the residents' name for Souq Mutrah. It appears to derive from the dark and crowded alleyways, which required hand-held lamps to navigate the market in the past [37]. 


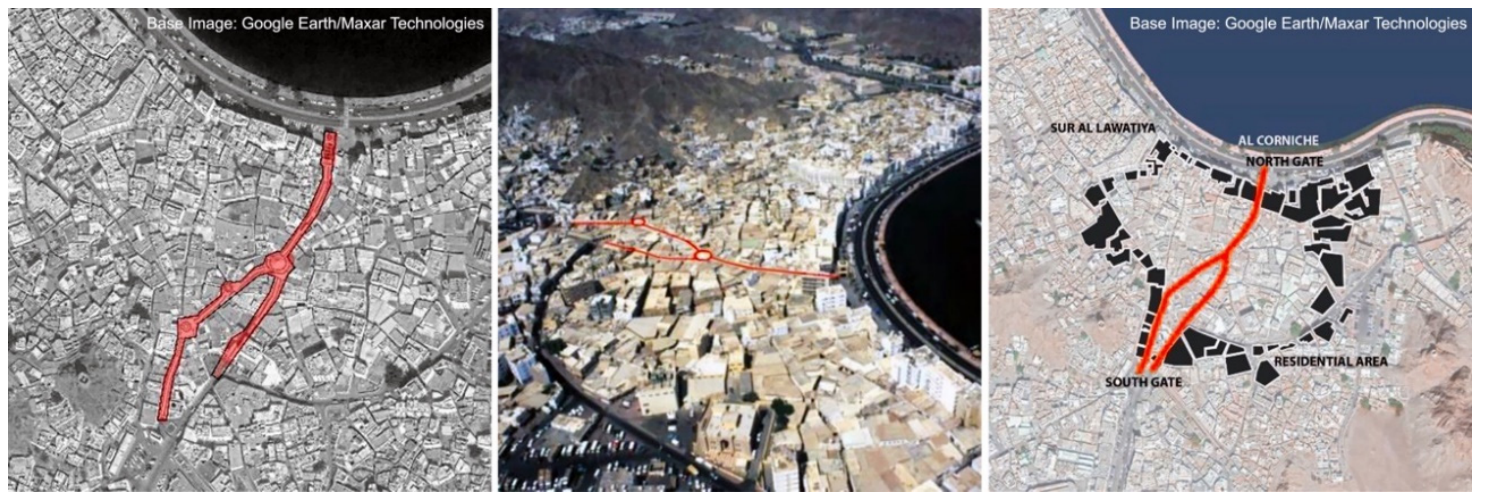

Figure 7. The main spine of Souq Mutrah highlighted in red (left) on a 2019 satellite image, (center) an aerial view of the Mutrah area, and (right) in combination with the blocks (in black) defining the boundary of the souq. Source: Drawings by Authors. Base satellite imagery courtesy of Google Earth/Maxar Technologies and middle image of Muscat Municipality [10,32].

The souq is opposite to the port of Mutrah, named Sultan Qaboos Port, which engaged in a great deal of trade during the age of the sailing ship due to its strategic location on the way to India and China. Today, it is primarily is a cruise terminal, attracting tourists from around the world, though the port also continues to provide support for the local fishing industry. Souq Mutrah covers an approximate area of 50,000 square meters $\left(\mathrm{m}^{2}\right)$, as measured using Google Earth tools. Mutrah was the commercial hub of Muscat from Portuguese occupation in the 16th century until the opening of the country during the reign of Sultan Qaboos from 1970-2020. Mutrah began to lose its importance as a commercial hub as the city expanded westward. Traditionally, Souq Mutrah consisted of two parts: one for retail goods and another for wholesale products such as food, textiles, household items and traditional Omani clothing. A diverse population of Arabs, Africans (primarily from East Africa), Pakistani, Indians and Persians characterized the area. However, Souq Mutrah evolved into a more localized souq catering more to residents in the immediate vicinity, as well as a growing expatriate community and tourists [25,37]. Today, Souq Mutrah still attracts local Omani customers, even as many locals shift their shopping habits to newer air-conditioned shopping malls in western Muscat. One of the most significant changes has been the increase in Western tourists and expatriate ('expat' in slang) residents, and the gradual disappearance of Shiite (Lawatiya and Khoja) and Hindu (Banjans) traders from the souq. They still own many of the shops but tend to rent retail spaces to Indian and Pakistani expat residents [12,37,38].

\section{About Souq Waqif and Doha}

The land in Qatar is generally flat along the coastline of the Arabian/Persian Gulf. It also tends to be extremely dry, with very few inlets. It was not always the case in the past along the Wadi musheireb inlet to the sea in Doha. The banks were frequently wet during the winter, which allowed merchants to sell goods while standing in the water. This curious characteristic gave rise to the name of Souq Waqif, which literally translates as 'standing market' ('سوق واقف') [39]. Initially, the souq was a weekly market mounted by the local Bedouins to sell goods, fish and pearls to traders from southern Iran and other Gulf countries.

Over time, Souq Waqif became a permanent market, selling goods from the Arabian Peninsula, India, Persia and East Africa. Shops aggregated and distributed linearly along a jetty perpendicular to the coast, forming what would become the historical spine of Souq Waqif. Residential quarters were adjacent to the northwest and southeast (refer back to Figure 3, right). A cemetery, prayer ground outside of the Souq Waqif Mosque, and the Turkish fort Al-Kuwt (or Al Koot) south of the cemetery came to define the western and southern edges of the market. Eventually, retailers established 
specialized areas selling similar products such as the Gold Souq, Spice Souq, Pet Souq, Clothing Souq and others, which remain to this day $[25,40]$.

Tannous and Major argue that the flat terrain in Qatar enabled the urban expansion of Doha to balance centrality and linearity at the macro-scale of the metropolitan region [9]. Doha grew in a relatively compact manner to the west, north, and south of Doha Bay; even somewhat to the east via land reclamation projects such as the Al Corniche, West Bay, The Pearl, Lusail City, Hamad International Airport and, to the extreme south, Hamad International Port. modern transportation planning helped to facilitate this compact nature of Doha through a successive series of ring roads, which gave shape to the distinctive superblock structure of the city today. The street density in metropolitan Doha is 36 streets $/ \mathrm{km}^{2}$, excluding airport lands and large vacant tracts of land in the periphery. It is consistent with average street density in the city centers of 20 American cities and, specifically, street density in the city center of Baltimore, maryland [36].

The cumulative effect helps to maintain the shallowness of Old Doha to the expanding edges of the metropolitan region. It primarily occurs via the radial route sequence of Wadi msheireb and Salwa Road, which is the longest, straightest street from Old Doha to the southwestern edge of the metropolitan region. Souq Waqif and msheireb Downtown Doha border the easternmost segment of this radial route sequence, which also connects to every ring road in the city, including the most important, i.e., D-Ring/Doha Expressway. Because of this, the metric distance from Old Doha to the furthest extents of the metropolitan region to the north, west and south is only $17 \mathrm{~km}$. This distance is nearly three times less than Old Muscat to the western edge of the Muscat metropolitan region [9].

This development pattern gave rise to a distinctive ortho-radial grid in the emergent spatial structure of metropolitan Doha, which is strongly consistent for the space syntax measures of integration and choice at the macro- and micro-scale $[9,22]$ (Figure 8). The configurational comparison of metropolitan Muscat and Doha in this research initially controlled for axial size, i.e., the number of streets represented as axial lines, based on Major's previous methodology [34,35]. The axial size was 21,376 lines in Muscat and 22,478 lines in Doha, representing a marginal difference $(<6 \%)$. The metric area of both metropolitan areas is also broadly similar: $720 \mathrm{~km}^{2}$ for Muscat and $650 \mathrm{~km}^{2}$ for Doha $(<11 \%$ difference). However, more than $50 \%$ of the land area in Muscat is unbuilt mountainous terrain [22]. Removing all one-connected lines from the space syntax model leads to stark differences in axial size. Nearly $26 \%$ of all streets in Muscat are one-connected lines or cul-de-sac sequences, primarily due to the mountainous terrain. Only $8 \%$ of all axial lines in Doha are one-connected lines or cul-de-sac sequences, which is comparable to European city centers [34].

A fair comparison of synergy includes one-connected lines and cul-de-sac sequences to maintain comparability in axial size and metric area. Synergy is a second-order measure in space syntax based on the $\mathrm{r}^{2}$ relationship between global and local integration, i.e., where you are locally in the urban spatial network relates to where you are globally in that network. Because of the development patterns arising from differing topographical conditions in these cities, synergy is over three times greater in metropolitan Doha $\left(R^{2}=0.388\right)$ compared to metropolitan Muscat $\left(R^{2}=0.115\right)$.

In the past, Souq Waqif used to bleed into and blend with surrounding residential neighborhoods (as shown in Figure 3), similar to Souq Mutrah. Today, due to modern transportation planning, Major urban streets define the perimeter of the Souq Waqif: Abdullah Bin Jasim Street/Souq Waqif Park to the north; Ali Bin Abdallah Street to the south; Banks Street, constructed in the 1980s, to the east; and Al-Asmakh Street/Msheireb Downtown Doha to the west (Figure 9). The Amiri Diwan complex, the royal palace of the Qatari Emir, sits to the immediate northwest of the souq. Ali Bin Abdullah Street is a continuation of the Salwa Road/Wadi msheireb radial route to the southwestern periphery of the metropolitan region. It eventually reaches the village of Abu Samra in the southwest corner of Qatar as one of only two roads providing overland access to Saudi Arabia. A continuation of Al Rayyan Road directly connects into the geometric center of Souq Waqif. Al Rayyan Road is another significant radial route in Doha that transitions into Al Rayyan Al Jedeed Street six kilometers $(\mathrm{km})$ further to the west, and 
it into the Durkan Highway $14 \mathrm{~km}$ away from the souq. The Durkan Highway connects ultimately across the Qatar Peninsula to the town of Durkan on the west coast.

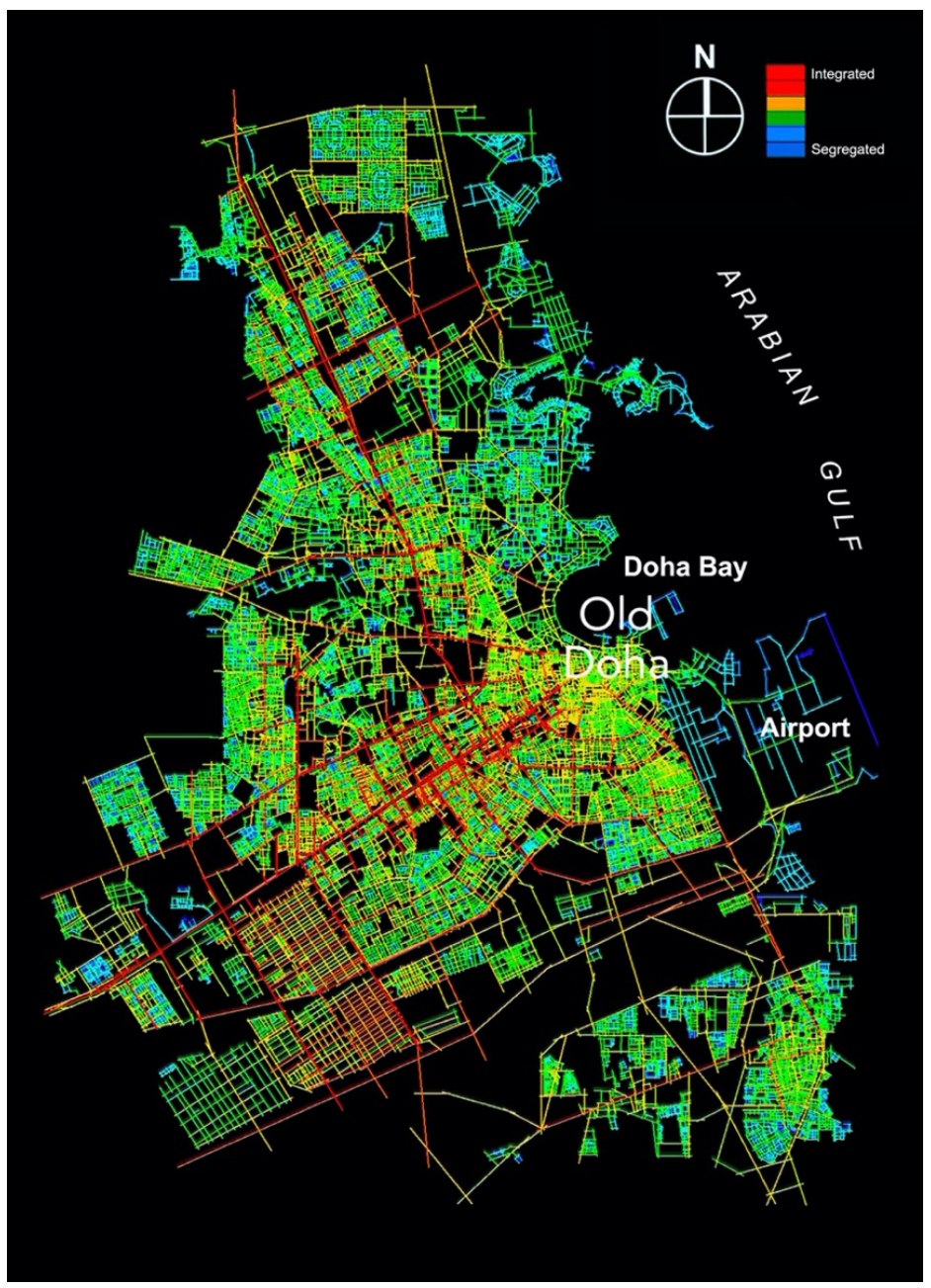

Figure 8. Pattern of integration (radius $=6$ ) in the space syntax model of metropolitan Doha, Qatar-based on mean depth from the most integrated street (6.4), i.e., Salwa Road—encompassing 20,473 streets without one-connected lines over an approximate area of $650 \mathrm{~km}^{2}$ in 2018.
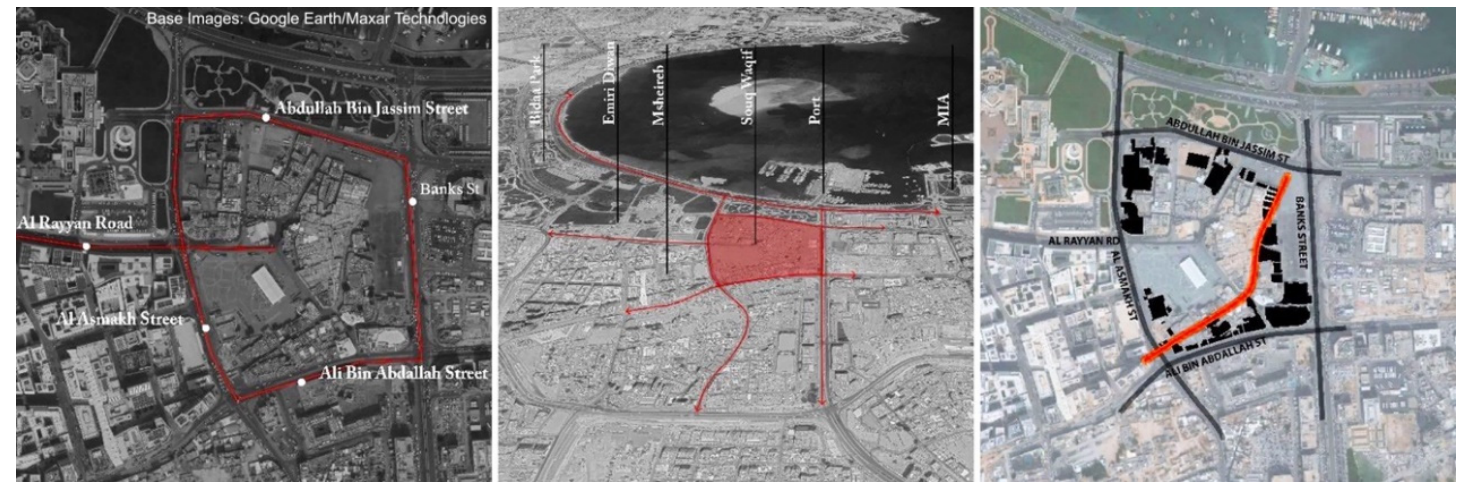

Figure 9. The area of Souq Waqif highlighted/outlined in red (left) on a 2019 satellite image, (center) an aerial view of the Old Doha area, and (right) the main spine (in red) in combination with the blocks/streets (in black) defining the boundary of the souq. Source: Drawings by Authors. Base satellite imagery courtesy of Google Earth/Maxar Technologies [13]. 
Souq Waqif was originally adjacent to the oldest port area on Doha Bay. The main port (now referred to the 'Old Port') shifted $\sim 1.5 \mathrm{~km}$ to the east due to the construction of Al Corniche during the late 1950s/early 1960s. The main port of Doha moved to the extreme south of the Al Wakrah settlement with the opening of Hamad International Port in 2018. However, portions of the Old Port still operate with a cruise terminal and fishing/recreation boat slips. It also includes the museum of Islamic Art with a surrounding park. One block away, Abdullah Bin Jasim Street parallels Al Corniche and the coast to the north. The approximate total area of Souq Waqif within these well-defined boundaries is $195,000 \mathrm{~m}^{2}$. However, this includes two large open plazas to the west (consistent with the old cemetery) and northeast, which account for about $20 \%$ of the effective area. The net area of the actual marketplace itself is $\pm 150,000 \mathrm{~m}^{2}$, or nearly three times the size of Souq Mutrah in Muscat [25].

\section{A Morphological Comparison: Findings and Discussion}

The urban fabric of Souq Mutrah and Souq Waqif today bear the hallmarks of their early development based on a process of the restricted random aggregation; the former more so than the latter $[22,24,25,35]$ (Figure 10). Adaptation becomes necessary as settlements become larger to maintain a degree of accessibility to the ever-expanding edges of the settlement in resolving Hillier's paradox of the principles of centrality and linearity in urban form $[23,35]$. Blocks tend to become more rectangular, and streets become broader/longer based on geometric principles. This process is more apparent in Old Doha in the surrounding areas of Souq Waqif, especially the amount of open space around the perimeter of the souq due to road widening, surface parking to the west, the Amiri Diwan complex and its surface parking lots to the northwest, and the Souq Waqif Park/Al Corniche to the north. Something similar also occurred in the Mutrah area, but on a smaller scale in relative terms; specifically, on $\mathrm{Al}$ Corniche along the coast, the broader southern segment of Mutrah High Street and the blocks further to the east, south and southeast. The amount of open space in the figure-ground representation of the Mutrah area is primarily due to coastline, Al Corniche and the Gulf of Oman to the north, and mountainous terrain to the southwest and southeast, where watchtowers are visible, i.e., small circular block forms.

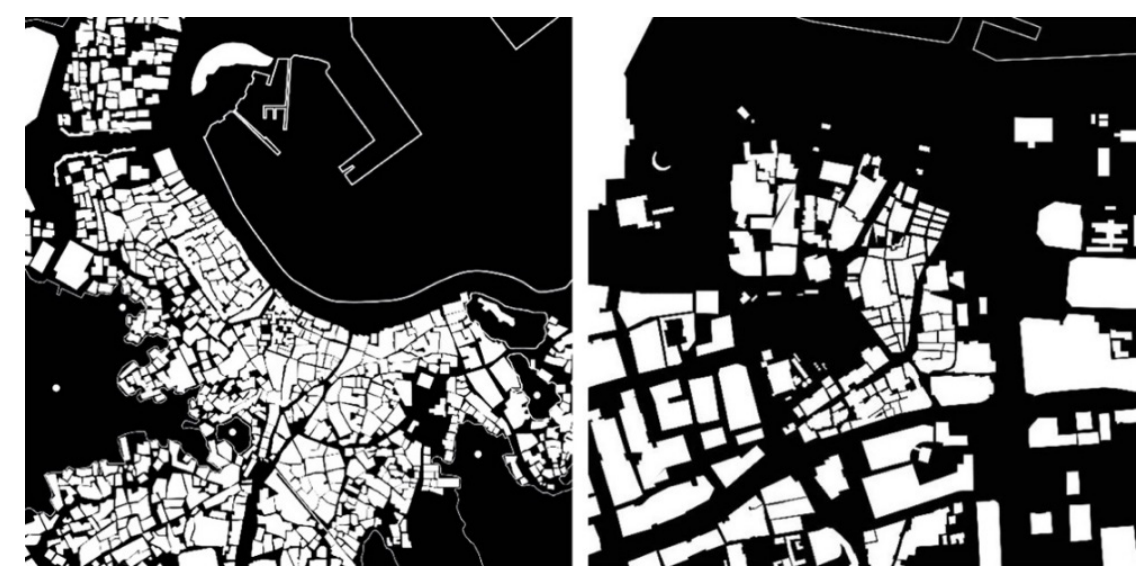

Figure 10. Figure ground representation (space in black, blocks/buildings in white) of a $1 \mathrm{~km}^{2}$ area of the urban fabric in (left) the Mutrah area of Muscat and (right) the Old Doha area including Souq Waqif and part of msheireb Downtown Doha in 2018.

However, their early development remains most apparent along the main spine of both souqs. Both spines consist of long pedestrian-only routes connecting via open-ended angles (within $15^{\circ}$ of a direct continuation), with most shorter routes connecting to the spine at right- or near-right angles $[25,41]$ (Figure 11). Retaining these morphological characteristics of the traditional urban fabric, including smaller block sizes, is a crucial component for promoting walkability in both souqs. The overwhelming majority of routes in both souqs are only for pedestrians. A pedestrian shed 
showing everything reachable within 300 and $400 \mathrm{~m}(\mathrm{~m})$ from the approximate geometric center of both souqs ably illustrates this point. (Figure 12). We selected pedestrian shed radii of $300 \mathrm{~m}$ and $400 \mathrm{~m}$ due to the hot climatic conditions on the Arabian Peninsula during much of the year. The industry-standard practice is radii of $400 \mathrm{~m}$ and $800 \mathrm{~m}$, consistent with a range of $\frac{1}{4}$ and $\frac{1}{2}$ mile or a 10 min walk. A $300 \mathrm{~m}$ and $400 \mathrm{~m}$ radius represents an unimpeded 3-5 min walk based on an average human walking speed of $1.4 \mathrm{~m} / \mathrm{second}$. Almost the entire Mutrah area is reachable within a 3-5 min walk. The areas outside of a $400 \mathrm{~m}$ distance are in the extreme northwest, where Al Bahri Road turns inland heading west, and the extreme southwest, where Mutrah High Street and At Towain Street diverge into parallel roads for about $300 \mathrm{~m}$ before converging together anew. Both Al Bahri Road and Mutrah High Street/At Towain Street head towards the broader Muscat region.
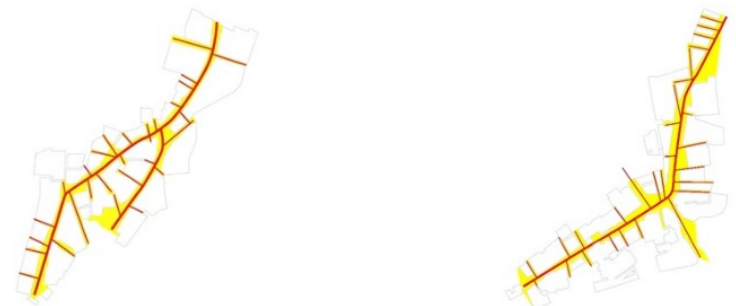

Figure 11. Illustration of the main spine composed of long lines connecting using open-ended angles with shorter lines connecting to the spine at right or near-right angles in (left) Souq Mutrah and (right) Souq Waqif.
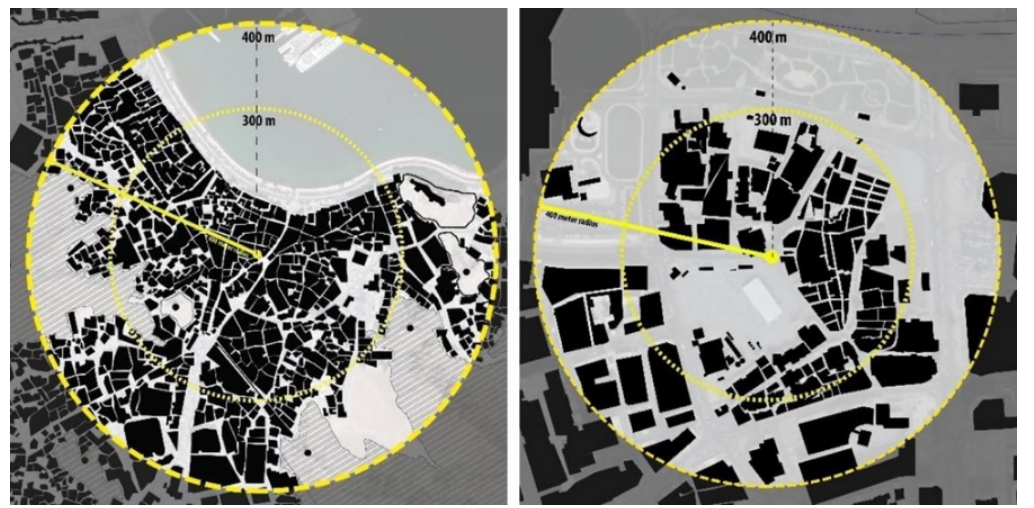

Figure 12. Pedestrian shed of a 3-5 min walk from the approximate geometric center of (left) Souq Mutrah and (right) Souq Waqif.

In Souq Waqif, almost every block lies within $300 \mathrm{~m}$ of the approximate geometric center of the area, except for the street corners at the intersections of the perimeter streets and building frontages along Ali Bin Abdallah Street to the south. However, these building frontages and the street corner intersections of Ali Bin Abdallah/Wadi msheireb/Al-Asmakh Street to the southwest, Ali Bin Abdallah/Banks Streets to the southeast, and Banks Street/Abdullah Bin Jasim Street to the northeast are easily accessible from the main spine of the souq. A large amount of open space around the perimeter of Souq Waqif is apparent. Almost all this space involves moving and stationary vehicular traffic, except for Souq Waqif Park to the north and the public plazas to the northeast and immediate southwest (associated with the old cemetery) of the geometric center.

The effect of modern interventions in Doha and the tendency towards a compact density in Muscat leads to a stark contrast when comparing the amount, size and shape of all of the urban blocks and free-standing buildings accessible within $300 \mathrm{~m}$ of the geometric center of both souqs (Figure 13). There are 314 blocks or buildings accessible within this distance from Souq Mutrah, with the largest block being $82 \mathrm{~m}$ along its most extended length. It includes the blocks of the Al-Lawatiyah Sur (inaccessible to non-residents), Mutrah Corniche promenade on both sides of the street, and many blocks and 
buildings within the surrounding residential neighborhoods. In contrast, there are only 82 blocks or buildings accessible within this distance from Souq Waqif, with the largest block having a length of $90 \mathrm{~m}(+9.8 \%)$. This accessible distance includes portions of blocks in msheireb Downtown Doha to the west, the open space of Souq Waqif Park to the north, and the entrances of the Gold Line metro Station and Barahat Al-Jufairi Park to the southeast. It also covers one side of Al Corniche to the north but does not include the street corners where there are pedestrian crosswalks to navigate across high vehicular flows on this road. There are almost four times as many blocks and buildings accessible within $300 \mathrm{~m}$ of Souq Mutrah compared to Souq Waqif. It seems apparent that there are a large number of squareand square-ish-shaped blocks available in both areas within a short distance, again more so in Muscat than Doha. However, this stark difference is primarily attributable to larger block sizes. It is also the consequences of the emergent superblock pattern arising from modern planning interventions in Doha, the 2004-2008 Souq Waqif restoration project, and the recently-completed msheireb Downtown Doha urban renewal project.
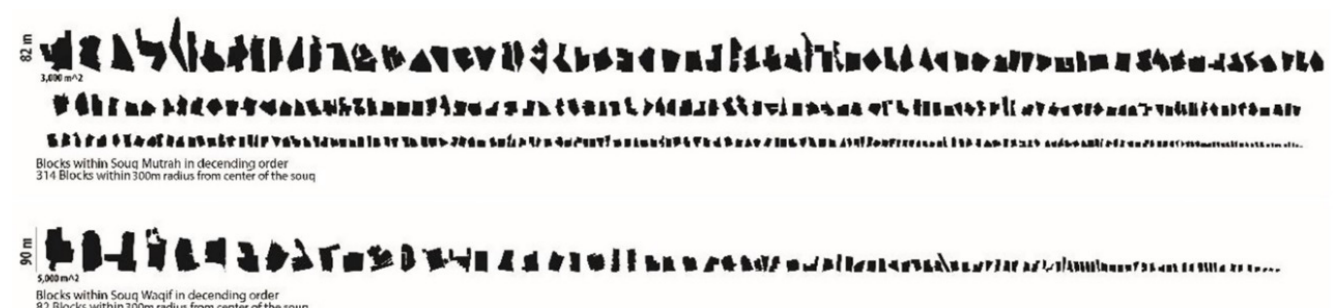

Figure 13. Rank ordering based on size—-from largest to smallest—of all of the urban blocks and free-standing buildings accessible within a radius of $300 \mathrm{~m}$ from the geometric center of (top) Souq Mutrah in Muscat and (bottom) Souq Waqif in Doha, set to the same scale.

Based on this, we could characterize the planning strategy for Souq Mutrah and the Mutrah area of Muscat in general terms as careful intervention along its perimeter, especially the northern edge associated with Mutrah Corniche/Al Bahri Road and the coastal port, and minimal intervention (or highly-localized interventions related to actions on individual dwelling units) within its interior. Muscat Municipality's Souq Mutrah Development Plan, the Development of Souq Mutrah and Corniche Mutrah, and the Beautification of Mutrah projects in 2004-2005 reflect this incremental approach to the preservation of Souq Mutrah. They focused on drainage, electrical distribution, security improvements, beautification along Mutrah Corniche and the construction of gateways at the northern and southern ends of the central spine on the perimeter to help denote main entry points to the souq (Figure 14).

In contrast, extensive intervention at its perimeter and in the surrounding urban context with more careful intervention within its interior appears to characterize the planning strategy for Souq Waqif in Doha. The 2004-2008 Souq Waqif Restoration project reflects this approach, despite involving the wholesale demolition of any buildings constructed after 1950 .

The reasons for and consequences of these differing planning strategies become apparent when we compare the accessibility catchment area of both souqs within their metropolitan region using space syntax. This analysis uses step-depth (e.g., changes of direction) in space syntax terms, based on the mean depth from the most integrated street as a common point of reference. For Muscat, this is 12.8, rounded off to 13, based on the mean depth from a long, central segment of Sultan Qaboos Street in Modern Muscat. For Doha, this is 6.4, rounded off to 6, based on the mean depth from the longest, straightest segment of Salwa Road. Both models utilize the fully-distributed urban spatial network, removing all one-connected lines and cul-de-sac sequences. 

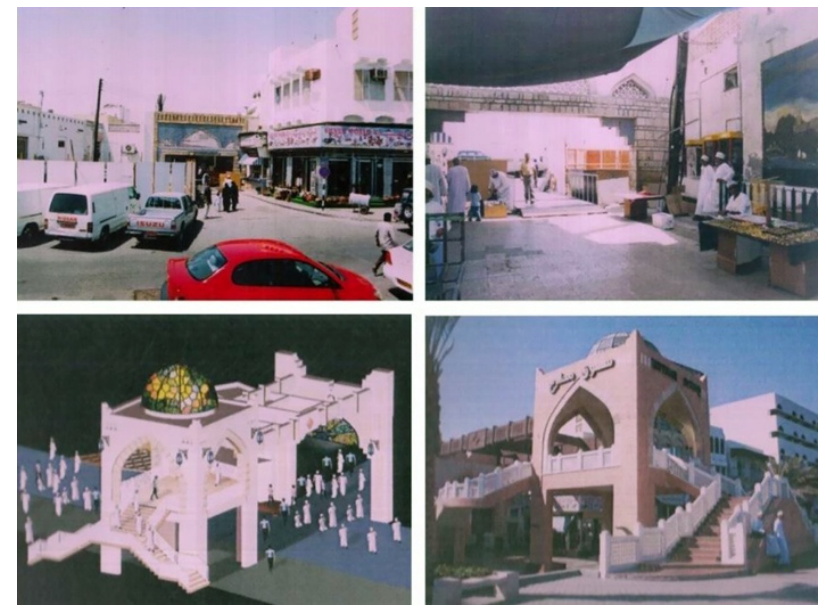

Figure 14. Views of the North Gate Development Project (top left) exterior situation before, (top right) interior situation before, (bottom left) the render of the design proposal, and (bottom right) after completion [42].

The local catchment area of all of the routes within, passing into, and defining the perimeter of Souq Mutrah up to 13 changes of direction away encompasses an approximate built area of only $6 \mathrm{~km}^{2}$ (Figure 15). It includes the Mutrah, Bayt Al Fajal and Ruwi areas in this part of Muscat, mostly south of the east-west route of Bab Al mathaib Street, which merges to become part of Sultan Qaboos Street further west. At its furthest linear extent, this only extends a distance as the crow flies of $3.5 \mathrm{~km}$.

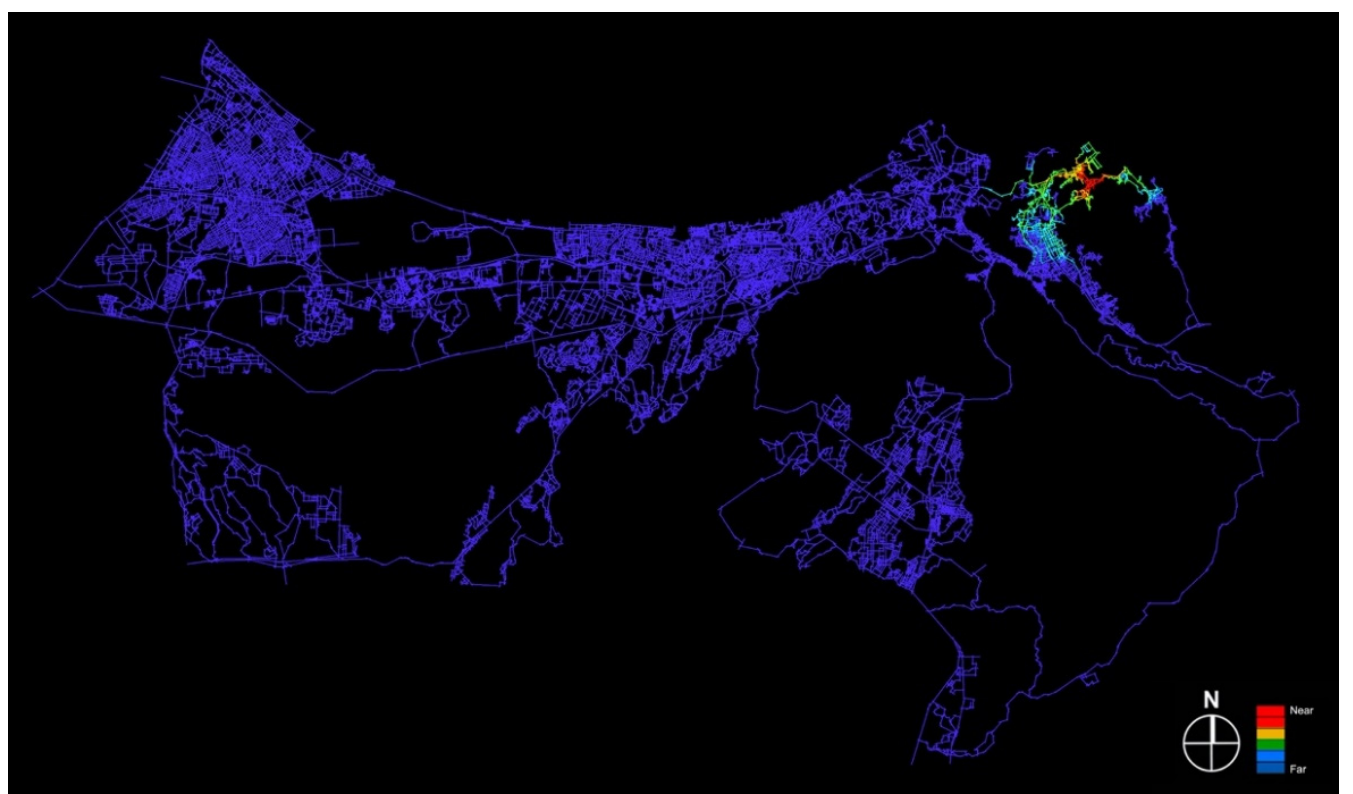

Figure 15. Step-depth based on 13 changes of direction from all streets within, passing into, and defining the perimeter of Souq Mutrah in the space syntax model of metropolitan Muscat in 2018.

In contrast, the local catchment area for all of the routes within, passing into, and defining the perimeter of Souq Waqif up to 6 changes of direction encompasses approximately $130 \mathrm{~km}^{2}$ of the urban fabric in Doha. It is nearly 22 times more area than that of Souq Mutrah. It includes almost everywhere within the C-Ring Road, except for large areas of the Al mansoura and Najma neighborhoods to the south. It extends to every ring road in a westerly direction and incorporates the entire perimeter of and distribution streets into the Industrial Area in the southwest of the metropolitan region. Furthermore, it includes linear extensions along Major routes to all edges of the metro region via Doha Expressway, 
Salwa Road and Al Wakra Road to the north ( 22 km), west ( 22 km) and south $(\sim 12 \mathrm{~km})$, respectively (Figure 16).

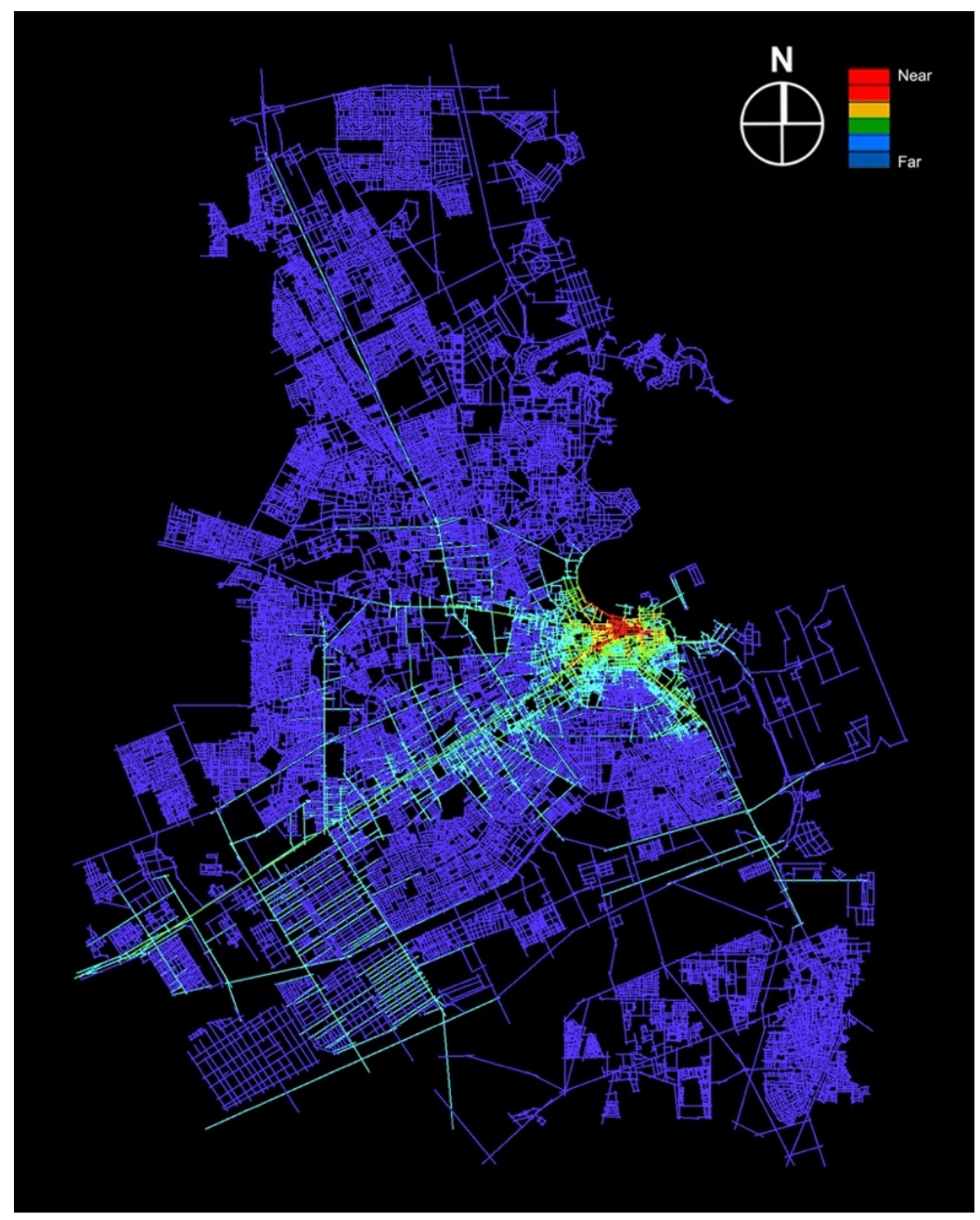

Figure 16. Step-depth based on 6 changes of direction from all streets within, passing into, and defining the perimeter of Souq Waqif within the space syntax model of metropolitan Doha in 2018.

The validity of these findings appears strengthened if we examine the local area effect, or grid intensification, of both souqs $[23,35]$. The scatter of integration (radius $=n$ vs. radius $=13$ ) in the space syntax model of metropolitan Muscat demonstrates a clustering effect related to the polycentric spatial structure of the city. The Al-Amaret, Mutrah, Mawaleh and Modern Muscat areas clearly distinguish (in ascending order for global integration) from one another. All of the routes within Souq Mutrah form a relatively focused grid intensification within the Mutrah cluster, hovering above the slope of correlation for the entire metropolitan region for Muscat (Figure 17, left). It appears to follow the clustering for the whole of the Mutrah area. 

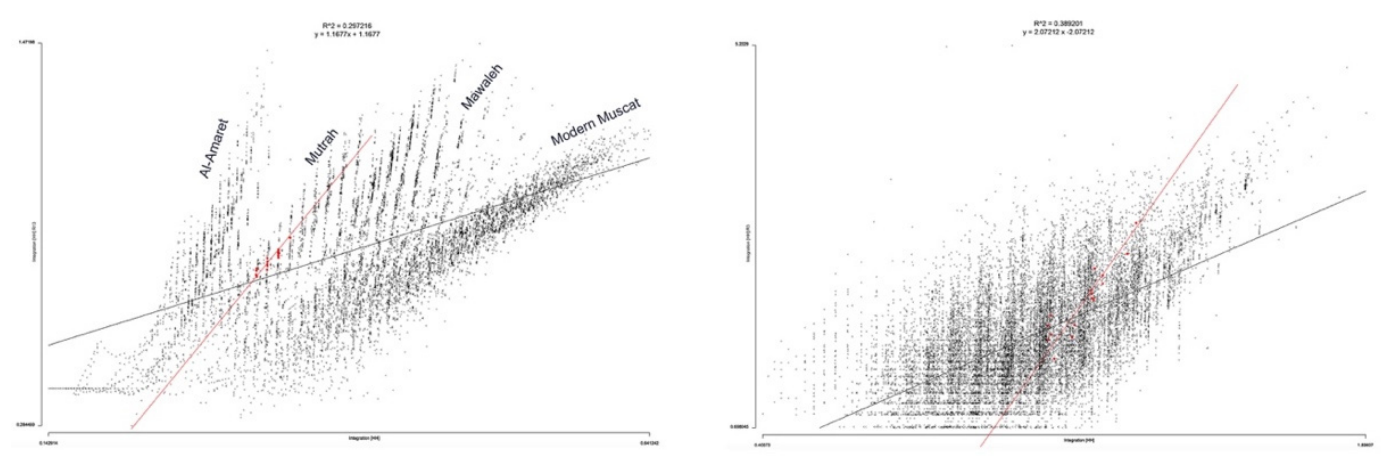

Figure 17. Scatter of (left) integration (radius $=n$ vs. radius $=13$ ) in metropolitan Muscat, with a characteristic distribution line for all of the routes within Souq Mutrah highlighted in red, and (right) global integration (radius $=n$ ) vs. local integration (radius $=3$ ) in metropolitan Doha, with a characteristic distribution line for all routes within Souq Waqif highlighted in red.

On the other hand, the routes within Souq Waqif appear to form a straightforward, or traditional in Hillierian terms, local area effect. There is a grid intensification in the relationship of synergy (correlation between global integration, radius $=n$ vs. local integration, radius $=3$ ) crossing over the slope of correlation for metropolitan Doha as a whole into the higher ranges of local integration [23,35] (Figure 17, right). The scatter of routes in Souq Waqif excludes two lines of sight extending from the Al Souq area about $50 \mathrm{~m}$ into the western portions of Souq Waqif, due to the contemporary creation of the northeast plaza. The construction of new retail units is currently underway in the northeast plaza of Souq Waqif, which will eliminate the extension of these two Al Souq routes into the souq, terminating them on its perimeter at Banks Street.

These conditions arose from the challenges of urban growth and development in the differing topographical conditions of these cities, and the need to adopt different strategies to preserve the long-term sustainability and viability of Souq Mutrah and Souq Waqif as traditional marketplaces $[9,25]$. Urban development in Muscat prioritizes linearity at the macro-scale and an intense form of centrality or locality at the micro-scale in giving rise to the emergent polycentric spatial structure of the urban pattern in the growing metropolis. Urban development in Doha balances both centrality and linearity at the macro-scale. In combination with a formal superblock pattern at the micro-scale in defining locality, this collectively helps to maintain the shallowness of Old Doha within the emergent ortho-radial spatial structure of the growing metropolis (Figure 18). Because of this, Souq Mutrah operates out of necessity as a local, everyday market for residents living in the immediate vicinity. It does cater to tourists and residents making the occasional, specific trip from further inland in Muscat, the cruise terminal in the old port, or both. However, this is supplementary to its primary role as a local traditional marketplace. Doha grew in a manner enabling Souq Waqif to fully transition from a local traditional marketplace into a cultural heritage district catering to everyday trips from almost everywhere in the metropolitan region. This transition became necessary due to a significant loss of residents living within the immediate vicinity of the souq. However, urban regeneration efforts supported by the Qatari government are well underway to bring residents (especially Qataris) back to Old Doha, such as the mixed-use msheireb Downtown Doha project [7,25]. 


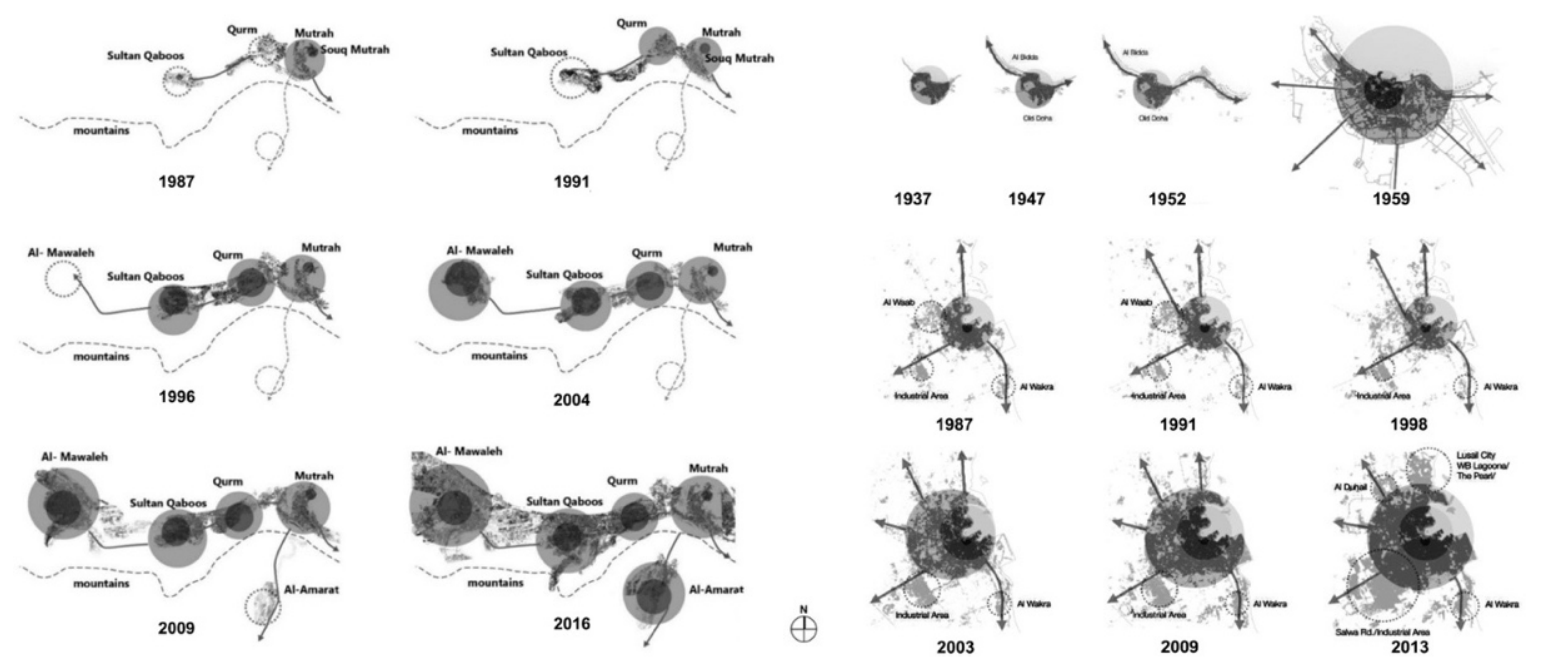

Figure 18. Illustration of Hillier's principles of centrality (represented as circles) and linearity (represented at lines) at work during urban growth over time in (left) six time periods of Muscat, 1987-2016, and (right) ten time periods of Doha, 1937-2013, giving rise to their distinctive emergent spatial.

\section{Implications for Future Research and Design Interventions}

Like many traditional markets in Arab cities, Souq Mutrah and Souq Waqif experienced a period of decline during globalization and rapid urbanization. It fed the shift of commercial development and activities to new, modern centers-such as indoor shopping malls, due to the harsh climatic conditions in the region-outside of the oldest areas of the city. The result was the negligence and degradation of traditional marketplaces such as souqs. In both of the cases in this paper, it meant physical and economic adaption to survive. Catering to international tourism became an essential attribute of their continuing socio-economic success as sustainable urban places, to one degree or another. For Souq Waqif in Doha, this meant a significant urban renewal project to restore its building fabric and reinvigorate the souq as a public place of significance in the city center. For Souq Mutrah in Muscat, this meant an economic adjustment to the realities of the expanding urban fabric in the city, and some specialization of the goods sold in the market catering to residents living in the immediate vicinity. Importantly, these case studies demonstrate that there is not any 'one size fits all' solution to the issue of socio-economic sustainability for traditional marketplaces in the Middle East; in fact, the opposite. It suggests that applying the solutions of one city to another in any design intervention for traditional markets might prove problematic without carefully accounting for the contextual relationship of such places within their city using objective tools such as space syntax.

\section{Conclusions}

We presented some of the findings for a study comparing form and function in two traditional markets: Souq Mutrah in Muscat, Oman, and Souq Waqif in Doha, Qatar. Globalization and rapid urbanization have characterized both Doha and Muscat over the last fifty years. Both cities have shared historical origins as coastal settlements, but with stark differences in topography. We investigated the urban morphology, land use and functioning of these souqs using several representation techniques typical of morphological research to contextualize these marketplaces within their metropolitan region on objective terms using tools such as space syntax analysis. The paper was able to develop an understanding of (1) the evolution of space and form in these marketplaces over time, and (2) the implications for their functioning as urban places today. The analysis demonstrated the critical importance of contextual relations at the macro- and micro-scale of the urban environment for understanding the complex socio-economic nature of these souqs. It helped to deepen our knowledge about traditional marketplaces and contemporary urbanism in the Arabian Gulf Region. In doing 
so, we demonstrated a critical link between the morphological evolution and economic vitality of markets, whereby different topological conditions and planning strategies for intervention can promote different solutions for the long-term sustainability of significant urban places. As we saw in this study, sustainable solutions remain fundamentally related to well-defined and understood spatial processes in all cities, including those of the Arabian Peninsula.

Author Contributions: Conceptualization, methodology, Software, Validation, Formal Analysis, Investigation, Data Curation, Writing-Original Draft Preparation, Writing-Review and Editing, Visualization, Supervision, Project Administration, Funding Acquisition; m.D.M. Conceptualization, methodology, Software, Validation, Formal Analysis, Investigation, Data Curation, Resources, Writing-Original Draft Preparation, Writing-Review and Editing, Visualization, Project Administration; H.O.T. All authors have read and agreed to the published version of the manuscript.

Funding: Some portions of this research involving the space syntax model of Metropolitan Doha in Qatar were supported by an internal grant from Qatar University (Grant ID: QUSD-CENG-2018/2019-4). Additional research was supported by a grant from the Qatar National Research Foundation (Grant ID: UREP25-002-5-001). Open access publication of this paper was jointly supported by Qatar National Library and the Qatar National Research Foundation.

Conflicts of Interest: The authors declare no conflict of interest.

\section{References and Notes}

1. Gharipour, M. The Bazaar in the Islamic City: Design, Culture, and History; The American University in Cairo Press: Cairo, Egypt, 2012.

2. Fletcher, R.; Carter, R.A. mapping the Growth of an Arabian Gulf Town: The Case of Doha, Qatar. J. Econ. Soc. Hist. Orient 2017, 60, 420-487. [CrossRef]

3. Forster, C. The Historical Geography of Arabia: Or, the Patriarchal Evidences of Revealed Religion: A memoir; Duncan and malcolm: London, UK, 1884.

4. Cotheal, A.I. Treaty between the United States of America and the Sultân of masḳat: The Arabic Text. J. Am. Orient. Soc. 2008, 4, 341-343.

5. Kostof, S. The City Assembled: The Elements of Urban form through History; Thames \& Hudson: London, UK, 1992.

6. Gehl, J. Cities for People; Island Press: London, UK, 2010.

7. Salama, A.M.; Wiedmann, F. Demystifying Doha: On Architecture and Urbanism in an Emerging City; Ashgate Publishing/Routledge: New York, NY, USA, 2013.

8. Chen, F. Urban morphology and Citizens' Life. In Encyclopedia of Quality of Life and Well-Being Research 9; michalos, A.C., Ed.; Springer: Dordrecht, The Netherlands, 2014; pp. 6850-6855.

9. Tannous, H.O.; Major, M.D. The Spatial Logic of the Arabian Coastal City: The Case of Doha, State of Qatar and Muscat, Sultanate of Oman. In Proceedings of the 5th ISUF-Italia 2020 Conference, Sapienza Università di Roma, Rome, Italy, 19-22 February 2020.

10. Figure ground of Mutrah: The authors constructed the base map using 1:500 screen grabs of Google maps/Maxar Technologies images in years 2012, 2013, and 2018. We then edited for better visual representation. The authors made corrections in the figure-ground drawings based on site visits, high resolution satellite images, and other sources such as the Historical Sur Allawatieya map (see Ferwati, 2012 below) and Functional Territorial Structure map of Mutrah in 1974 (see Scholz, 2014 below).

11. Ferwati, M.S. Beautiful Things That We miss in Space Syntax. Arts Des. Stud. 2012, 4, 1-11.

12. Scholz, F. Muscat: Then and Now; Druckaus Kothen GmbH \& Co.: Berlin, Germany, 2014.

13. Figure Ground of Doha: The authors constructed the base map using 1:500 screen grabs of Google maps/Maxar Technologies images in years 2014, 2016, and 2018. We then edited for better visual representation. The authors made corrections in the figure-ground drawings based on site visits, high resolution satellite images, and planning reports available from Doha Municipality at Qatar University Archive Library, Doha, Qatar (see below).

14. Doha Municipality. Doha Inner City Redevelopment; Doha Municipality: Doha, Qatar, 1985.

15. Doha Municipality. Doha Inner City Redevelopment; Doha Municipality: Doha, Qatar, 1986.

16. John Lockerbie. Catnaps. 2015. Available online: http://catnaps.org/islamic/protect.html (accessed on 8 June 2019). 
17. Kiet, A. Arab Culture and Urban Form. Focus 2011, 8, 36-45. [CrossRef]

18. Lynch, K. The Image of the City; mIT Press: Cambridge, mA, USA, 1960.

19. Alexander, C.; Neis, H.; Anninou, A.; King, I. A New Theory of Urban Design; Oxford University Press, Inc.: New York, NY, USA, 1987.

20. Zmewer, S.M. Arabia: The Cradle of Islam; Fleming H. Revell Company: New York, NY, USA, 1900.

21. Original Photograph in the Embassy of the State of Qatar, Bangkok, Thailand. Available online: http: //www.qatarembassy.or.th/imgs/qatar_info_history2.jpg (accessed on 14 may 2018).

22. Major, M.D.; Tannous, H.O.; mirincheva, V. Urban Transformations: From restricted random aggregation to designed cultural intent in Middle Eastern cities. In Proceedings of the 12th International Space Syntax Symposium Proceedings, Beijing Jiao Tong University, Beijing, China, 8-13 July 2019; Volume 282, pp. 1-15.

23. Hillier, B. Space Is the machine: A Configurational Theory of Architecture; Cambridge University Press: Cambridge, UK, 1996.

24. Hillier, B.; Hanson, J. The Social Logic of Space; Cambridge University Press: Cambridge, UK, 1984.

25. Tannous, H.O. Traditional markets in Context: A morphological Comparison of Souq Waqif in Doha, Qatar and Mutrah Souq in Muscat, Oman. master's Thesis, Qatar University, Doha, Qatar, 2020.

26. Benkari, N. Urban Development in Oman: An Overview. In Proceedings of the 9th International Conference on Sustainable Development \& Planning, WIT Transactions on Ecology and The Environment, Wessex Institute, Bristol, UK, 27-29 June 2017; Volume 226, pp. 143-156. [CrossRef]

27. Al-Marri, F.H.M.A. The Impact of the Oil Crisis on Security and Foreign Policy in GCC Countries: Case Studies of Qatar, KSA and UAE; Arab Center for Research and Policy Studies Research Paper; Doha Institute: Doha, Qatar, 17 November 2017; Available online: https:/www.dohainstitute.org/en/ResearchAndStudies/Pages/The-Impactof-the-Oil-Crisis-on-Security-and-Foreign-Policy-in-GCC-Countries-Case-Studies-of-Qatar,-KSA-and-UAE. aspx (accessed on 21 June 2020).

28. Wippel, S.; Bromber, K.; Krawietz, B. Under Construction: Logics of Urbanism in the Gulf Region; Routledge: New York, NY, USA; London, UK, 2014.

29. Wiedmann, F.; Salama, A.M.; Ibrahim, H.G. The Role of mega Projects in Redefining Housing Development in Gulf Cities. Open House Int. Spec. Issue Archit. Urban. Glob. South 2016, 41, 56-63.

30. World Bank. Middle East \& North Africa. Available online: https://data.worldbank.org/region/middle-eastand-north-africa (accessed on 29 July 2020).

31. US Department of Energy. Available online: https://www.eia.gov/international/data/world\#/ (accessed on 29 July 2020).

32. Muscat Municipality from Al-Maimani, A.; Salama, A.M.; Fodil, F. Exploring Socio-Spatial Aspects of Traditional Souqs: The Case of Souq Mutrah, Oman. Int. J. Archit. Res. 2014, 8, 50-66.

33. Qatar museums. Urban Fabric of Old Doha-Our Projects. Available online: https://www.qm.org.qa/en/ cultural-heritage-management-urban-fabric-projects (accessed on 29 July 2020).

34. Major, M.D. The Invention of a New Scale: The paradox of size and configuration in American cities. J. Space Syntax 2015, 6, 170-191.

35. Major, M.D. The Syntax of City Space: American Urban Grids; Routledge: New York, NY, USA; London, UK, 2018.

36. Lexico in Collaboration with Oxford English Dictionary. Available online: https://www.lexico.com/definition/ corniche (accessed on 29 July 2020).

37. Ganatra, A. Souq Al Dhalam-The Dark Souq of Oman. Everything Oman. 2017. Available online: https: //everythingoman.blog/2017/02/23/souq-al-dhalam-the-dark-souq-of-oman/ (accessed on 27 June 2020).

38. Scholz, F. Muscat, Sultanat Oman: Geographische Skizze Einer Einmaligen Arabischen Stadt; Dar Arabische Buch: Berlin, Germany, 1990.

39. Radoine, H. Souk Waqif On-Site Review Report. 2010. Available online: https://archnet.org/sites/6449/ publications/1924 (accessed on 26 June 2020).

40. Alraouf, A. A Tale of Two Souqs: The Paradox of Gulf Urban Diversity. Open House Int. 2012, 37, 72-81. 
41. Hillier, B. The hidden geometry of deformed grids: Or, why space syntax works, when it looks as though it shouldn't. Environ. Plan. B Plan. Des. 1999, 26, 169-191. [CrossRef]

42. Muscat Municipality. Development of Souq Mutrah and Corniche Mutrah, and Beautification of Mutrah; Muscat Municipality: Muscat, Oman, 2005.

(C) 2020 by the authors. Licensee MDPI, Basel, Switzerland. This article is an open access article distributed under the terms and conditions of the Creative Commons Attribution (CC BY) license (http://creativecommons.org/licenses/by/4.0/). 